\title{
Analisis Kelayakan Bisnis Usaha Depot Air Minum Isi Ulang (Studi Kasus Pada R.O Qua Kabupaten Lahat)
}

\author{
Jalaludin \\ Sekolah Tinggi Ilmu Ekonomi Serelo Lahat, jalaludin0126@gmail.com
}

\begin{abstract}
ABSTRAK
Penelitian ini dilakukan dengan tujuan menganalisis kelayakan bisnis usaha Depot Air Minum Isi Ulang (DAMIU) RO Qua Kabupaten Lahat yang telah beroperasi selama 6 tahun. Dalam menganalisis kelayakan bisnis usaha tersebut digunakan empat parameter yaitu Net Present Value, Payback Period, Profitability Index, dan Average of Return. Hasil analisis kelayakan bisnis DAMIU RO Qua Kabupaten Lahat dengan nilai investasi awal sebesar Rp 90.500.000 menunjukkan bahwa Net Present Value diperoleh nilai positif sebesar + Rp. 145.338.690. maka dapat dikatakan bahwa usaha DAMIU RO Qua Kabupaten Lahat layak untuk dilaksanakan. Hasil perhitungan Payback Period didapatkan bahwa DAMIU RO Qua Kabupaten telah mendapatkan kembali modal awal dalam waktu 2 tahun 8 bulan 8 hari. Berdasarkan perhitungan Profitability Index diperoleh nilai 2,61 yang berarti rencana tersebut dapat dikatakan layak dilaksanakan. Berdasarkan penghitungan, investasi DAMIU RO Qua Kabupaten Lahat memiliki nilai Average of Return sebesar 37\%. Nilai tersebut selanjutnya bisa dimanfaatkan oleh pihak investor untuk memberikan permodalan sesuai dengan minimum rate yang dikehendaki.
\end{abstract}

Kata Kunci: Analisis Kelayakan Bisnis, Aspek Keuangan, Air Minum Isi Ulang

\section{ABSTRACT}

This study was conducted with the aim of analyzing the business feasibility of RO Qua Refill Drinking Water Depot (DAMIU) in Lahat Regency which has been operating for 6 years. In analyzing the feasibility of the business, four parameters are used, namely Net Present Value, Payback Period, Profitability Index, and Average of Return. The results of the business feasibility analysis of DAMIU RO Qua Lahat Regency with an initial investment value of Rp. 90,500,000 indicate that the Net Present Value obtained is a positive value of $+R p .145,338,690$. it can be said that the DAMIU RO Qua business in Lahat Regency is feasible to carry out. The results of the Payback Period calculation show that DAMIU RO Qua District has recovered its initial capital within 2 years 8 months 8 days. Based on the calculation of the Profitability Index obtained a value of 2.61, which means the plan can be said to be feasible. Based on the calculation, the investment of DAMIU RO Qua in Lahat Regency has an Average of Return value of $37 \%$. This value can then be used by investors to provide capital in accordance with the desired minimum rate.

Keywords: Business Feasibility Analysis, Financial Aspects, Refill Drinking Water

\section{A. PENDAHULUAN}

Usaha Depot Air Minum Isi Ulang (DAMIU) yang terlihat sederhana dan peluang usaha yang cukup menjanjikan menyebabkan banyak pesaing bermunculan yag membuat terjadinya persaingan ketat untuk menarik minat konsumen membeli air isi ulang di RO Qua Kabupaten Lahat. Selain itu, evaluasi dan tinjuan sangat harus dilakukan untuk mencegah hal buruk yang terjadi di masa depan seperti kerugian hingga kebangkrutan. Bukan hanya untuk pemilik usaha, evalusi juga diperlukan sebagai informasi bagi masyarakat untuk mempertimbangkan aspekaspek dari depot air isi ulang yang akan dibeli.

Studi kelayakan adalah suatu kegiatan yang mempelajari secara mendalam tentang suatu kegiatan atau usaha yang akan dijalankan, untuk menentukan layak atau tidaknya suatu bisnis dijalankan (Kasmir dan Jakfar 2012). Tujuan dilakukannya 
studi kelayakan bisnis ini adalah untuk memperkirakan seberapa besar potensi usaha tersebut dapat berjalan menghasilkan keuntungan. baik dalam situasi mendukung maupun situasi yang tidak mendukung dalam jangka panjang atau jangka pendek. Serta pengambilan keputusan untuk mengembangkan suatu usaha juga membutuhkan dasar studi kelayakan untuk mendapatkan hasil (output) yang maksimal dan mengurangi resiko kegagalan yang mungkin terjadi.

Dalam kegiatan studi kelayakan bisnis suatu usaha, terdapat aspek-aspek yang menjadi titik fokus yang perlu dipertimbangkan dengan teliti salah satunya berupa aspek finansial yaitu analisis keuangan usaha tersebut. Dalam aspek ini, kita perlu menggunakan analisis kriteria investasi yang meliputi NPV (Net Present Value), IRR (Internal Rate of Return), B/C (Benefit Cost Ratio), PBP (Payback Period). Hasil analisa ini diperlukan untuk mengetahui apakah kegiatan usaha ini akan menguntungkan secara ekonomis atau tidak, karena kegiatan yang dilakukan oleh suatu bisnis usaha pada umumnya bertujuan untuk mendapatkan keuntungan secara ekonomis. Mengingat usaha depot air isi ulang R.O Qua Kabupaten Lahat sudah berdiri selama 6 tahun dan belum pernah melakukan studi kelayakan untuk usahanya. Maka dari itu, penulis tertarik melakukan penelitian mengenai bagaimana kelayakan bisnis usaha depot air minum isi ulang R.O QUA Kabupaten Lahat.

\section{B. KAJIAN TEORI}

\section{1) Pengertian Studi Kelayakan Bisnis}

Menurut Kasmir dan Jakfar (2012:7) studi kelayakan bisnis atau usaha adalah kegiatan yang mempelajari secara mendalam atau bisnis yang akan dijalankan, dalam rangka menentukan layak tidaknya usaha tersebut dijalankan. Untuk menentukan layak tidaknya suatu usaha dapat dilihat dari berbagai aspek. Setiap aspek untuk dapat dikatakan layak harus memiliki suatu standar nilai tertentu, namun keputusan penilaian tak hanya dilakukan pada salah satu aspek saja. Penilaian untuk menentukan kelayakan harus didasarkan kepada seluruh aspek yang akan dinilai nantinya. Studi kelayakan usaha juga merupakan penelitian terhadap rencana bisnis yang tidak hanya menganalisis layak atau tidaknya bisnis dibangun, tetapi juga saat dioperasionalkan secara rutin dalam rangka pencapaian keuntungan yang maksimal untuk waktu yang tidak ditentukan (Umar, 2015).

\section{2) Aspek Finansial}

Aspek finansial dianalisis untuk mengetahui jumlah biaya yang akan dikeluarkan dan pendapatan yang akan diterima serta menentukan proporsi pemenuhan sumber dana, yaitu melalui pinjaman, modal sendiri, atau investor. Terdapat tiga kegiatan utama dalam penilaian aspek finansial, yaitu membuat rekap penerimaan, membuat rekap biaya, dan menguji aliran kas masuk yang dihasilkan berdasarkan kriteria kelayakan yang ada. Metode penilaian yang digunakan sebagai berikut:

a) Payback Period (PP)

Payback Period (PP) merupakan metode untuk menghitung lamanya waktu atau periode yang diperlukan dalam pengembalian uang telah diinvestasikan dari aliran kas masuk (proceed) tahunan yang dihasilkan oleh proyek investasi tersebut. 
b) Net Present Value (NPV)

Net Present Value (NPV) merupakan metode yang dilakukan dengan membandingkan nilai sekarang aliran kas masuk bersih dengan nilai sekarang investasi. Selisih antara nilai sekarang keduanya tersebut yang disebut Net Present Value (NPV) (Kasmir dan Jakfar, 2012: 103).

c) Profitability Index (PI)

Menurut Kasmir dan Jakfar (2012), Profitability index (PI) atau benefit and cost ratio $(\mathrm{B} / \mathrm{C}$ rasio) adalah rasio aktivitas dari jumlah nilai sekarang penerimaan bersih dengan nilai sekarang pengeluaran investasi selama umur investasi.

d) Average Rate of Return (ARR)

Average Rate of Return (ARR) adalah metode yang digunakan untuk mengukur tingkat keuntungan yang diperoleh dari suatu investasi. Tingkat keuntungan yang digunakan adalah laba setelah pajak dibandingkan dengan total atau ratarata investasi.

\section{3) Air Minum Dalam Kemasan (AMDK)}

Air minum adalah air yang melalui proses pengolahan atau tanpa proses pengolahan yang memenuhi syarat untuk dapat diminum. Sementara itu, Air Minum Dalam Kemasan (AMDK), berdasarkan pada pengertian yang diambil dari Standar Nasional Indonesia (SNI) adalah air baku yangtelah diproses, dikemas, dan aman diminum mencakup air mineral dan air demineral.

\section{METODE PENELITIAN}

1) Jenis Penelitian

Penelitian ini termasuk kedalam jenis penelitian lapangan (field research) adalah suatu penelitian yang dilakukan secara sistematis dengan mengangkat data yang ada di lapangan (Arikunto, 2015: 58). Penelitian ini adalah penelitian deskriptif kualitatif dengan menggunakan data primer dan sekunder.

2) Tempat dan Waktu Penelitian

Penelitian ini dilakukan pada usaha Depot Air Minum Isi Ulang (DAMIU) RO Qua Kabupaten Lahat. Waktu penelitian dari bulan Mei sampai dengan bulan September 2021.

3) Populasi dan Sampel

Populasi diambil selama 6 tahun terakhir dari tahun 2015-2020 dengan melihat kebutuhan air minum untuk wilayah kota Lahat dengan sampel komponen modal tetap usaha.

4) Teknik Pengumpulan Data

Sumber data dalam penelitian ini terdiri dari sumber data primer yang berasal dari pengamatan dan wawancara, dan sumber-sumber data skunder yang di dapat dari dokumen-dokumen yang berkaitan dengan penelitian. Adapun teknik pengumpulan data dalam penelitian ini adalah observasi, wawancara dan dokumentasi. 
Instrumen utama dalam penelitian kualitatif adalah peneliti sendiri atau anggota tim peneliti. Sugiyono (2018:400) menyatakan bahwa peneliti membutuhkan alat bantu guna menyimpan data dan informasi yang didapat dari sumber data dalam penelitian. Alat bantu tersebut juga dapat digunakan sebagai bukti telah dilakukannya penelitian dan pengambilan data. Alat bantu dalam penelitian ini adalah pedoman wawancara, lembar observasi dan dokumentasi.

5) Teknik Analisis Data

Analisis data sangat penting dalam suatu penelitian karena di dalam analisis data dilakukan pengorganisasian terhadap data yang berkumpul di lapangan. Analisis dan penelitian ini menggunakan teknik analisis deskriptif kualitatif. Teknik analisis deskriptif kualitatif dilakukan dengan mengumpulkan data secara mendalam melalui (observasi, wawancara, dan dokumentasi) dan menganalisis data tersebut hingga menjadi penyusunan laporan.

D. HASIL PENELITIAN DAN PEMBAHASAN

Tabel Hasil Analisis Finansial Usaha AMDIU RO dan Ozonisasi

\begin{tabular}{|c|c|c|c|c|c|}
\hline Uraian & $\begin{array}{c}\text { PBP } \\
\text { (tahun) }\end{array}$ & $\begin{array}{c}\text { NPV } \\
\mathbf{( R p )}\end{array}$ & $\begin{array}{c}\text { B/C } \\
\text { ratio }\end{array}$ & $\begin{array}{c}\text { BEP } \\
\text { (Galon) }\end{array}$ & $\begin{array}{c}\text { IRR } \\
\text { (\%) }\end{array}$ \\
\hline DAMIU RO & 4,67 & 145.338 .690 & 2,61 & 38.330 & 37 \\
\hline DAMIU Ozonisasi & 4,78 & 105.475 .821 & 2,89 & 33.240 & 25 \\
\hline
\end{tabular}

Setelah penulis mendapatkan data terkait dengan biaya investasi dan biaya operasional AMDK Banyu Mili, selanjutnya Penulis akan melakukan analisis kelayakan investasi dengan menggunakan metode Net Present Value (NPV), Payback Period (PP), Profitability Indeks (PI), serta Average Rate of Return (ARR).

1) Net Present Value (NPV)

Perhitungan NPV dilakukan dengan mencari selisih nilai sekarang dari aliran kas masuk bersih dengan nilai pengeluaran untuk investasi. Pada perhitungan nilai NPV, diperoleh nilai positif sebesar + Rp. 145.338.690. Dengan demikian, nilai NPV adalah positif atau lebih dari 0, maka dapat dikatakan bahwa usaha DAMIU RO Qua Kabupaten Lahat layak untuk dilaksanakan.

2) Payback Period

Metode penilaian kelayakan dengan Payback Period digunakan untuk menghitung lama periode yang dibutuhkan untuk mengembalikan dana investasi yang sudah dikeluarkan. Penghitungan payback period digunakan sebagai acuan investor dalam menilai pengembalian dana investasi yang dikeluarkan untuk membiayai usaha DAMIU RO Qua Kabupaten Lahat. Payback period dihitung dengan membagi nilai investasi dengan rata-rata proceeds atau aliran kas bersih yang masuk. Berdasarkan analisis pada bagian biaya investasi, diperlukan dana sebesar Rp. 90.500.000. Setelah dilakukan penghitungan di Microsoft Excel dengan metode payback period, didapatkan bahwa DAMIU RO Qua Kabupaten telah mendapatkan kembali modal awal dalam waktu 2 tahun 8 bulan 8 hari. 
3) Profitability Indeks

Penghitungan kelayakan menggunakan metode Profitability Indeks hampir sama seperti pengitungan NPV, yaitu dengan terlebih dahulu mengetahui Present Value dari Proceeds atau kas masuk bersih dan penyusutan serta Present value dari Outlays atau investasi yang dikeluarkan pada masa sekarang. Metode profitabilitas Indeks dihitung dengan membandingkan present value dari penerimaan kas bersih dengan nilai investasi. Suatu investasi dikatakan layak apabila nilai PI lebih besar dari 1. Hasil penghitungan pada DAMIU RO Qua Kabupaten Lahat menunjukan bahwa nilai PI memiliki nilai 2,61 yang berarti rencana tersebut dapat dikatakan layak dilaksanakan.

4) Average of Return

Penghitungan kelayakan investasi menggunakan metode Average of Return digunakan untuk menghitung persentase keuntungan yang diperoleh dari suatu investasi. Caranya adalah dengan membagi rata-rata laba setelah pajak dengan investasi awal lalu dikalikan 100\%. Berdasarkan penghitungan, investasi DAMIU RO Qua Kabupaten Lahat memiliki nilai ARR sebesar 37\%. Nilai tersebut selanjutnya bisa dimanfaatkan oleh pihak investor untuk memberikan permodalan sesuai dengan minimum rate yang dikehendaki.

\section{E. KESIMPULAN DAN SARAN}

1. Kesimpulan

Penelitian ini menganalisa kelayakan bisnis usaha Depot Air Minum Isi Ulang RO Qua Kabupaten Lahat dengan fokus penelitian terhadap aspek finansial yang menggunakan laporan keuangan tahunan usaha yang bersangkutan. Dari hasil analisa tersebut maka dapat disimpulkan sebagai berikut :

a) Hasil analisis kelayakan dengan perhitungan net present value menunjukkan bahwa DAMIU RO Qua Kabupaten Lahat telah memenuhi kriteria kelayakan usaha yang sudah ditetapkan, diperoleh nilai positif sebesar + Rp. 145.338.690. Sedangkan hasil analisis kelayakan dengan perhitungan profitability indeks menunjukkan bahwa usaha DAMIU RO Qua Kabupaten Lahat layak dilaksanakan sebab nilai PI lebih besar dari 1. Hasil penghitungan pada DAMIU RO Qua Kabupaten Lahat menunjukan bahwa nilai PI memiliki nilai 2,61 yang berarti rencana tersebut dapat dikatakan layak dilaksanakan.

b) Berdasarkan analisis kelayakan dengan perhitungan payback period menunjukkan bahwa DAMIU RO Qua Kabupaten yang telah berjalan selama 6 tahun, telah mendapatkan kembali modal awal yang digunakan dalam kurun waktu 2 tahun 8 bulan 8 hari.

c) Hasil analisis kelayakan dengan perhitungan average of return investasi DAMIU RO Qua Kabupaten Lahat memiliki nilai ARR sebesar 37\%.

\section{Saran}

Berdasarkan hasil analisa yang telah dilakukan oleh peneliti, maka untuk usaha DAMIU RO Qua Kabupaten Lahat, peneliti dapat memberikan saran yaitu menambah kapasitas produksi dengan memperluas jangkauan pendistribusian air isi ulang. Sebab, modal awal yang digunakan sudah kembali dan jumlah penjualan hanya sedikit mengalami kenaikan setiap tahunnya. Hal ini menjadi potensi DAMIU RO Qua Kabupaten Lahat untuk meningkatkan potensi penjualan. 


\section{DAFTAR PUSTAKA}

Arikunto, Suharsimi. (2015). Dasar-Dasar Research. Bandung: Tarsoto

Kasmir dan Jakfar. (2012). Studi Kelayakan Bisnis. Jakarta: Kencana.

Sugiyono. (2018). Metode Penelitian Kuantitatif Kualitatif Dan R\&D . Bandung: Alfabeta.

Tim. Reality. (2012). Kamus Terbaru Bahasa Indonesia Dilengkapi Ejaan Yang Benar. Jakarta: PT. Reality Publisher, h. 450.

Umar, Husein. (2015). Studi Kelayakan Bisnis Edisi 3. Jakarta: PT. Gramedia Pustaka Utama 